\title{
Market Arrival and Price Behaviour Analysis of Potato in Four Major Markets in India
}

\author{
Nandini Saha", Amit Kar, Girish K Jha, P Venkatesh and Pramod Kumar
}

Division of Agricultural Economics, ICAR-Indian Agricultural Research Institute, New Delhi-110012, India

*Corresponding author: nansnew@gmail.com (ORCID ID: 0000-0001-7180-6587)

Received: $20-08-2020$

Revised: $25-11-2020$

Accepted: 08-12-2020

\begin{abstract}
Vegetable plays key role in providing nutrition to human body. Vegetables are major sources of vitamins, minerals, fiber, iron, calcium etc. Potato is the highest yielding vegetable in the world as well as in India. It is one of the significant vegetables of Indian consumer's food basket. Despite of high production, due to seasonal production and perishable nature market arrival and price are highly volatile in nature. So, the present study was conducted with an intension to study the trend in arrival and price of potato in four major markets in India along with their Compound Annual Growth Rate (CAGR) and seasonality and variability associated with them. The study is based on secondary data collected from www.agmarknet. gov.in. Data was collected for the period March 2009 to March 2019, and the analysis was done based on that. Linear trend in arrival and nominal prices were found to be positive across the markets, however for real prices, it was found negative except Bangalore (₹ 5.50/q per annum). CAGR for arrival in all the four markets were found positive, and for real prices it was negative in most of the months. The main season of arrival of potato in different markets was December to March, and for prices index is highest during the off season. Variability in arrival is highest in Agra market and in price variability is highest in Azadpur market.

\section{Highlights}

( CAGR of arrival were found positive, however for real prices it was negative in most of the months across the markets.

(0 Trend in arrival and nominal prices were found to be positive in all the four markets, however for real price, it was found negative except Bangalore market.

o Seasonal price index was found highest during the off season.
\end{abstract}

Keywords: Vegetables, Potato, Compound Annual Growth Rate, Trend, Seasonality, Variability

Vegetables are the most vital element in human diet which supply vitamins, minerals, fiber, iron, calcium etc. to human body. Since vegetables can be grown in various ecological condition present in India, it exercises a great influence in vegetable production. India is the second largest producer of vegetables just after China. Vegetable sector is considered to be very important because it generates high income and employment, improve nutrition, protects and conserves the ecology (Kumar et al. 2005). Vegetables are highly perishable in nature which leads to the large variations in output and wide fluctuation in the prices which exposes the vegetable growers to high risk. Potato is the most important vegetable and food crop in India. Marketable surplus of potato crop is higher than other food crops but due to perishability and seasonality, price fluctuations are more. Higher price volatility in potato is a major concern for the farmers. Several findings have shown that potato prices fall every alternate year as a result of the market glut situation (Singh et al. 2017). Their price

How to cite this article: Saha, N., Kar, A., Jha, G.K. Venkatesh, P. and Kumar, P. (2020). Market Arrival and Price Behaviour Analysis of Potato in Four Major Markets in India. Economic Affairs, 65(4): 529-533.

Source of Support: None; Conflict of Interest: None (क) 9 
volatility is largely due to changes in output and eventual changes in market arrivals (Latwal et al. 2017) and also because of supply disruptions. The supply disturbances tied with short-term demand and supply elasticity, contribute to sharp price fluctuations. The condition for vegetable growers is further exacerbated by lack of information on potential market as well as potato arrival \& price behaviour (Singh et al. 2017). Relatively inelastic demand for potato and higher price fluctuations at retail level lower the consumer welfare (Bera et al. 2017). Therefore, information regarding market arrival and price behaviour is very important for producer as it helps in finding out the best time for marketing to fetch higher profit (Thakare et al. 2017). With this background, the present study attempted to evaluate the market arrival and price behaviour of potato in four major markets.

\section{MATERIALS AND METHODS}

The present study of analysing arrival and price behaviour of potato is based on the secondary data. Daily price data of the major markets from March 2009 to March 2019 were collected from www. agmarknet.gov.in and weekly prices (Rupees per quintal) were calculated. Agra, Azadpur, Bangalore and Burdwan markets are selected as major markets on the basis of market arrival and data availability of potato.

\section{Analytical Framework}

To achieve the objective of the study, these statistical techniques have been used:

\section{Compound Annual Growth Rate}

The growth rates can be specified as the percentage change of a particular variable within a given period of time. Compound annual growth rates (CAGR.s) of price \& arrival of the selected vegetables for each month over the ten-year period were estimated using the following growth model:

$$
Y=\alpha \beta^{x}
$$

Where,

$Y=$ Price/ arrival of vegetables for the year $t, t$ $=$ Time variable $(1,2 \ldots \ldots n)$ for each period, $\alpha=$ Constant, $\beta=$ Growth coefficient
Log transformation of above function is:

$$
\ln Y t=\ln \alpha+t(\ln \beta)
$$

Where, $\ln \beta=\ln (1+r)$ and $t=[\operatorname{antilog}(\ln \beta)-1]$

$$
\mathrm{CAGR}=[\operatorname{antilog}(\ln \beta)-1] * 100
$$

\section{Linear Trend}

The linear trends of market arrivals and prices of the vegetables were observed through the linear trend equations in the form of linear regression as under,

$$
Y=\alpha+\beta t
$$

Where, $Y=$ Market arrival/ Price of the crops, $\alpha=$ Intercept coefficient, $\beta=$ Regression coefficient, $t=$ time variable

\section{Cuddy-Della-Valle Index}

Variability can be calculated from the simple coefficient of variation also, but it often overestimates the level of instability in time series data due to the presence of long-term trend, so, Cuddy - DellaValle index was constructed to correct the flaws present in coefficient of variation. Cuddy Della Valle Index was used to estimate variability in price $\&$ arrival of selected vegetables. The variability coefficient has been computed using the following formula,

$$
C-D-V \text { Index }=C V^{*} \sqrt{ }\left(\left(1-R^{2}\right)\right.
$$

Where $C V=(\mathrm{SD} / \mathrm{Mean}){ }^{*} 100$ and $R^{2}$ is the adjusted estimated coefficient of determination

\section{Seasonal Fluctuations}

The seasonality in market arrival and price behaviour was studied using multiplicative model of the following type,

$$
Y_{t}=T_{t} * S_{t} * C_{t} * I_{t}
$$

Where,

$Y_{t}=$ Wholesale prices/market arrivals of Potato (₹/q), $T_{t}=$ Trend value at time $t, S_{t}=$ Seasonal fluctuation at time $t, C_{t}=$ Cyclic fluctuation at time $t, I_{t}=$ 
Irregular fluctuation at time $t$. It provides an index for evaluating the degree of the seasonal variation present in a time series.

\section{RESULTS AND DISCUSSION}

Potato tends to show wider fluctuations in output due to seasonal and perishable nature which lead to vivid fluctuations in price. Several factors contribute to the price instability, among them the fluctuations in market arrivals play a big role. Thus, there is a need to identify the behaviour of prices and market arrivals over a period of time.

\section{Compound Annual Growth Rate}

CAGR is a very useful measure of growth over multiple time period. CAGR value gives the idea about the percentage change of price and arrival over the years. The CAGR values presented in table 1 indicates that in Agra market the CAGR values for market arrival is positive in all months and in Burdwan and Bangalore markets except one-month. The positive CAGR value of market arrival indicates constructive growth of arrival over those months. But in Azadpur market the scenario is different, where negative growth of arrival was observed for half of the months in the year. For all the four the markets, CAGR values for prices were negative for most of the months implying that in those months real prices have been adversely affected over the years though there is increase in nominal prices.

In different markets, highest positive CAGR of market arrival was observed during August to October which may be attributed to high nominal price during those months which positively affects the supply. Also, it can be found that in different months Burdwan market's arrival has grown the most over the years which is even more than Agra which is another big potato market. These may be due to better market intelligence, better transportation facilities as well as reduction in postharvest losses etc.

\section{Linear Trend analysis}

The linear trend is used to compute the long-run movement of market arrivals and prices of potato during the period under study in the selected markets. The results are given in table 2-4. The coefficient of arrivals of potato is negative in Azadpur market which indicate that the arrivals of potato in these markets was decreasing over time. In case of Agra, Bangalore and Burdwan, which are the major potato producing centers, the positive coefficient indicated the increase in potato arrivals in the study period. In the long run, the per annum decrease in arrivals potato over the years in Azadpur is 2731.44 quintals, and the per annum increase in arrivals in Agra is 20259.72 qtls, Bangalore 10117.23 qtls and in Burdwan 26434.85 qtls. In case of nominal prices of potato, the coefficients were found to be positive in all of the selected markets. The highest annual increase in potato prices was seen in Bangalore ( $₹ 47.70 / q$ ) followed by Burdwan (₹ 25.86/q), Agra market (₹ 23.70/q) and the lowest in Azadpur market (₹ 13.84/q). However, the linear trend of real prices decreased over time except Bangalore market where

Table 1: Month wise Compound Annual Growth Rate (CAGR) of real price and market arrivals of potato

\begin{tabular}{lllllllll}
\hline & \multicolumn{7}{c}{ Markets } \\
\cline { 2 - 9 } & Agra & & Azadpur & & Bangalore & \multicolumn{3}{c}{ Burdwan } \\
\hline Months & Arrivals & Real Price & Arrivals & Real Price & Arrivals & Real Price & Arrivals & Real Price \\
\hline January & 4.53 & -3.63 & 0.04 & -3.20 & 3.40 & -0.54 & 6.77 & -2.20 \\
February & 0.48 & -1.07 & 0.95 & -2.37 & 1.54 & 0.23 & -3.60 & 0.37 \\
March & 0.44 & 0.33 & -0.88 & -2.74 & -0.52 & 1.99 & 1.67 & 4.39 \\
April & 10.95 & -0.57 & -2.87 & -1.79 & 1.52 & 6.19 & -9.25 & 2.21 \\
May & 8.24 & -1.12 & -2.13 & -2.02 & 4.84 & 3.78 & 7.77 & 2.06 \\
June & 3.90 & -0.67 & 1.11 & -2.83 & 3.98 & 1.98 & 19.57 & 1.33 \\
July & 5.01 & -1.95 & -1.28 & -2.66 & 7.32 & 0.20 & 27.98 & -0.30 \\
August & 8.72 & -2.73 & -1.29 & -0.85 & 2.69 & 2.10 & 26.64 & -0.64 \\
September & 5.74 & -2.47 & 1.51 & -2.21 & 13.33 & 2.79 & 22.67 & -2.66 \\
October & 33.56 & -1.65 & 0.38 & -2.15 & 6.36 & 1.74 & 24.72 & -2.76 \\
November & 8.91 & -3.39 & -2.02 & -2.98 & 9.15 & -0.58 & 16.85 & -2.97 \\
December & 10.39 & -6.48 & -2.59 & -4.99 & 4.76 & -3.92 & 26.13 \\
\hline
\end{tabular}


real price has increased by $₹ 5.50 / q$ per annum though there is increasing trend in nominal prices.

Table 2: Trend in arrivals of potato

\begin{tabular}{llll}
\hline Sl. No & Markets & Intercept & Coefficient \\
\hline 1 & Agra & 336414.6 & 20259.72 \\
2 & Azadpur & 369525.1 & -2731.44 \\
3 & Bangalore & 232010.6 & 10117.23 \\
4 & Burdwan & 38243.0 & 26434.85 \\
\hline
\end{tabular}

Table 3: Trend in nominal prices of potato

\begin{tabular}{llll}
\hline Sl. No & Markets & Intercept & Coefficient \\
\hline 1 & Agra & 646.72 & 23.70 \\
2 & Azadpur & 831.22 & 13.84 \\
3 & Bangalore & 1026.945 & 47.70 \\
4 & Burdwan & 740.86 & 25.86 \\
\hline
\end{tabular}

Table 4: Trend in real price of potato

\begin{tabular}{llll}
\hline S1. No & Markets & Intercept & Coefficient \\
\hline 1 & Agra & 19288.07 & -9.32 \\
2 & Azadpur & 30648.4 & -14.92 \\
3 & Bangalore & -10255.3 & 5.50 \\
4 & Burdwan & 15818.91 & -7.56 \\
\hline
\end{tabular}

\section{Seasonal Indices}

Seasonal shifts in business activity that occur on a regular basis each year is known as Seasonal variation. Seasonal variation in arrival and price of potato is a known fact. The market arrival of perishable crops is mainly determined by different human and organizational factors along with the climatic situation. Very weak farmers' bargaining power, lack of storage facilities and high perishability and increasing demand for ready cash and lack of market intelligence compel farmers to sell their produce instantly after harvest (Ali et al. 2018).

Seasonal arrival indices table indicates that in Agra market the arrival indices of potato was found to be highest during December January and lowest in July. During December January arrival remains on the higher side and consequently price indices remained low during that time and lower arrival indices coincides with the higher price indices during the lean season. In Bangalore and Burdwan market the arrival indices were on the higher side during the month of March - April because of the glut created in the market because the rabi crop enters the market. In these two markets also the price indices remained much lower during the period of higher arrival. In Azadpur market the arrival indices is found to be highest during October - November along with higher prices.

\section{Variability}

C-D-V index is used to measure the instability or variability in the data, the instability of both market arrival and price of potato in the sample markets has been calculated using the index. The result of analysis of variability in market arrival and prices is presented in table 6. Variability in prices is more pronounced than market arrival. Variability in market arrival is found highest in Agra market with an index of $42.5 \%$, while Bangalore market showed the lowest value with index of $21.30 \%$. Variability in

Table 5: Seasonal indices of market arrivals and prices of potato

\begin{tabular}{|c|c|c|c|c|c|c|c|c|}
\hline \multirow[b]{3}{*}{ Months } & \multicolumn{8}{|c|}{ Markets } \\
\hline & Agra & & Azadpur & & Bangalore & & Burdwan & \\
\hline & Arrivals & Price & Arrivals & Price & Arrivals & Price & Arrivals & Price \\
\hline January & 119.7 & 65.7 & 106.2 & 63.7 & 100.5 & 91.5 & 34.1 & 61.9 \\
\hline February & 115.7 & 59.9 & 97.6 & 59.3 & 96.9 & 82.9 & 34.1 & 56.4 \\
\hline March & 115.4 & 73.6 & 107.1 & 67.5 & 114.7 & 78.9 & 701.4 & 74.7 \\
\hline April & 106.9 & 82.4 & 100.5 & 81.9 & 94.7 & 91.3 & 211.1 & 93.5 \\
\hline May & 108.8 & 96.1 & 87.0 & 92.6 & 96.2 & 106.1 & 50.8 & 113.1 \\
\hline June & 87.4 & 111.2 & 78.5 & 112.0 & 97.3 & 111.4 & 33.7 & 113.6 \\
\hline July & 76.8 & 126.7 & 86.7 & 122.8 & 90.5 & 112.6 & 33.1 & 114.6 \\
\hline August & 97.2 & 123.9 & 86.0 & 128.3 & 100.9 & 105.0 & 26.6 & 115.7 \\
\hline September & 80.7 & 120.6 & 94.8 & 137.1 & 105.0 & 100.4 & 24.0 & 119.7 \\
\hline October & 79.4 & 128.7 & 101.7 & 139.7 & 95.3 & 106.1 & 18.2 & 125.0 \\
\hline November & 89.0 & 124.9 & 129.0 & 123.3 & 97.9 & 111.6 & 21.5 & 121.1 \\
\hline December & 121.3 & 85.6 & 125.4 & 71.2 & 110.6 & 100.7 & 25.0 & 88.2 \\
\hline
\end{tabular}


prices were quite high in all the 4 market, however Azadpur market showed the highest variability with a index of $53.17 \%$ and Bangalore market which accounted for the lowest variability in market arrival has also exhibited the lowest variability in prices.

Table 6: Variability of market arrival and prices in all markets

\begin{tabular}{lll}
\hline \multicolumn{3}{c}{ C-D-V Index (\%) } \\
\hline Markets & Market Arrival & Price \\
\hline Agra & 42.5 & 51.79 \\
Azadpur & 26.32 & 53.17 \\
Bangalore & 21.30 & 30.35 \\
Burdwan & 30.74 & 48.11 \\
\hline
\end{tabular}

\section{CONCLUSION}

Compound Annual Growth Rate (CAGR) calculation of both arrival and prices has revealed that growth of arrival is positive in majority of the months across the markets. However, for real price the scenario is opposite. Real price has shown negative growth in maximum months. The CAGR indicates that though over the years market arrival in most of the months have grown positively, real prices have actually recorded negative growth. Linear trend also depicts same result. Market arrivals have increased over the years across the markets except Azadpur. Nominal prices have also risen, but real market prices have fallen in three markets except Bangalore. CAGR and Trend both depicts that in spite of increasing arrival and nominal prices, the condition of the producers has actually worsened since there is negative growth and negative trend of real prices over the years. Seasonality calculation revealed that seasonal index of arrival is highest during the period Dec-March, which is the main season for potato in India. But for price across the markets index is highest during the off season which may be due to the reason that off-season crop fetches good price and more income to the growers. Cuddy-Della-Valle Index revealed that variability in both market arrival and prices are on the higher side but variability in price is more than that of arrival. This is because potato price is subjected to high volatility.

\section{REFERENCES}

Ali, J., Kachroo, J., Bhat, D.J. and Bhat, A. 2018. Analysis of Prices and Arrivals of Apple Fruit in Narwal Market of Jammu. Economic Affairs, 63(1): 107-111.

Bera, B., Dutta, J. and Nandi, A. 2017. A study on the variability in market arrivals and prices of potato in some selected markets of West Bengal. International Journal of Agricultural Sciences, 9(40): 4621-4625.

Kumar, V., Sharma, H.R. and Singh, K. 2005. Behaviour of market arrivals and prices of selected vegetable crops: A study of four metropolitan markets. Agricultural Economics Research Review, 18(2): 271-290.

Latwal, M. and Kumar, A. 2017. Market arrival and price behaviour of potato in Uttarakhand. International Journal of Development Research, 7(1): 11219-11225.

Singh, D.K., Pynbianglang, K. and Pandey, N.K. 2017. Market Arrival and Price behaviour of Potato in Agra district of Uttar Pradesh. Economic Affairs, 62(2): 341-345.

Thakare, H.P., Daundkar, K.S., Rathod, S.R. and Bondar, U.S. 2017. Changes and trends in arrival and prices of agricultural commodities in APMC Kolhapur market. International Research Journal of Agricultural Economics and Statistics, 8(1): 26-30. 
